\title{
KARAKTERISTIK GABUNGAN KELOMPOK TANI PENERIMA PROGRAM PENGEMBANGAN USAHA AGRIBISNIS PEDESAAN (Kasus di Kecamatan Siak Kecil Kabupaten Bengkalis Riau) ${ }^{1}$
}

\author{
Susy Hartatit ${ }^{2}$, Amiruddin Saleh ${ }^{3}$, Basita Ginting Sugihen ${ }^{4}$ \\ ${ }^{1}$ Bagian dari tesis yang disampaikan pada Ujian Magister Sains KMP \\ ${ }^{2}$ Lulusan Pascasarjana Komunikasi Pembangunan Pertanian dan Pedesaan IPB Bogor. \\ Alamat email: uchy_171275@yahoo.co.id \\ ${ }^{3}$ Ketua Komisi Pembimbing, Dosen Mayor KMP Pascasarjana IPB \\ ${ }^{4}$ Anggota Komisi Pembimbing, Dosen Mayor KMP Pascasarjana IPB
}

\begin{abstract}
Rural Agribusiness Development Program (PUAP) is a program that focuses in reducing poverty and also creating a huge accupation in rural area by providing venture capital to support on farm and off farm activities. Farmers' association (Gapoktan) as an implementer of PUAP has a pivotal function to distribute incentives, venture capital, and also as the managers of all the programs given. Gapoktan is an association of some farmer groups that collected and worked together for increasing the economic scale and effort efficiency which have several characters. The objectives of this research was to describe the characteristic of Gapoktan. This research resulted several important usults, namely: The characteristics were categorized good, where the indicators of norm, the purposes, cohesive, leadership and participation were good categorized, while the indicator of size was less categorized, and than Gapoktan were still became a hope for the farmers in increasing and developing their farm activities.
\end{abstract}

Keywords: farmers' association (Gapoktan), characteristic, PUAP.

\section{PENDAHULUAN}

Kemiskinan di perdesaan merupakan masalah pokok nasional yang penanggulangannya tidak dapat ditunda dan harus menjadi prioritas utama dalam pelaksanaan pembangunan kesejahteraan sosial karena dapat menimbulkan ketimpangan dalam masyarakat dan merupakan tantangan dalam mewujudkan masyarakat yang sejahtera. Masyarakat miskin pada umumnya kurang mempunyai kemampuan dalam berusaha dan memiliki akses yang terbatas terhadap peluang-peluang yang ada seperti kurangnya akses kepada sumber permodalan, pasar dan teknologi, serta organisasi tani yang masih lemah. Oleh karena itu pembangunan ekonomi nasional berbasis pertanian dan perdesaan secara langsung maupun tidak langsung dapat berdampak pada pengurangan penduduk miskin. Selama ini pembangunan pertanian secara luas lebih terfokus pada produksi namun sekarang mulai beralih pada sistem dan usaha agribisnis yang berorentasi pada kelompok.

Pemerintah meluncurkan Program Nasional Pemberdayaan Masyarakat Mandiri (PNPM-M). Salah satu kegiatan dari PNPM-M di Kementerian Pertanian adalah kegiatan 110 
Vol 6, No 2, Oktober 2011: $110-123$

Pengembangan Usaha Agribisnis Perdesaan (PUAP) yang telah dilaksanakan sejak tahun 2008 dalam rangka menanggulangi kemiskinan dan pengangguran di desa-desa yang basis pertaniannya cukup tinggi, program ini dimaksudkan untuk para petani miskin yang belum tersentuh oleh modal perbankan sementara mereka memiliki usaha pertanian yang produktif dan dilakukan secara partisipatif, dengan memberikan bantuan modal dalam bentuk bantuan langsung masyarakat yang digunakan untuk membiayai kegiatan on farm dan off farm.

Gabungan kelompok tani (Gapoktan) merupakan kelembagaan tani sebagai pelaksana PUAP dalam hal penyaluran insentif bantuan modal usaha bagi petani/peternak serta pengelolaan program secara keseluruhan. Gapoktan PUAP adalah kumpulan beberapa kelompok tani (Poktan) yang bergabung dan bekerja sama untuk meningkatkan skala ekonomi dan efisiensi usaha yang memiliki berbagai karakteristik tertentu. Kehidupan Gapoktan tak lepas dari karakteristik kelompok pembentuk Gapoktan itu sendiri dalam berinteraksi, kelompok yang ideal adalah kelompok yang dapat menjalankan fungsinya sebagai sebuah kelompok yang utuh, di mana pola hubungan antarpribadi yang berlaku di dalam kelompok sudah tercipta dengan baik. Sehingga Gapoktan diharapkan dapat menjadi suatu kelembagaan ekonomi milik petani yang memiliki kemampuan dan mandiri, dengan demikian mereka diharapkan dapat tumbuh dan berkembang menjadi petani yang mampu berswadaya dan berswadana dalam upaya meningkatkan pendapatan dan kesejahteraan keluarganya.

Peraturan Menteri Pertanian No: 273/Kpts/OT.160/4/2007 pada Lampiran 1, menerangkan bahwa pengembangan kelompok tani diarahkan pada peningkatan kemampuan setiap kelompok tani dalam menjalankan fungsinya, peningkatan kemampuan para anggota dalam mengembangkan agribisnis, penguatan kelompok tani menjadi organisasi petani yang kuat dan mandiri. Kelompok tani yang berkembang bergabung ke dalam Gapoktan (Deptan 2007).

Kecamatan Siak Kecil adalah salah satu kecamatan penerima dana PUAP di Kabupaten Bengkalis sejak tahun 2008 sampai tahun 2010 dengan jumlah Gapoktan penerima bantuan sebanyak delapan Gapoktan yang meliputi bidang usaha peternakan dan tanaman pangan.

Berdasarkan hal tersebut, penelitian ini ingin melihat karakteristik Gapoktan dalam mengimplementasikan program PUAP, sehingga permasalahan yang menarik untuk diteliti adalah seperti apakah karakteristik Gapoktan penerima dana PUAP di Kecamatan Siak Kecil Kabupaten Bengkalis?

Berkaitan dengan permasalahan yang telah dikemukakan, maka tujuan penelitian ini adalah untuk mendeskripsikan karakteristik Gapoktan penerima dana PUAP di Kecamatan Siak Kecil Kabupaten Bengkalis. 


\section{METODE PENELITIAN}

Penelitian dilakukan di Kecamatan Siak Kecil Kabupaten Bengkalis Provinsi Riau. Penentuan lokasi penelitian dilakukan dengan sengaja, yang mempertimbangkan adanya keterwakilan tahun masuknya program PUAP ke Kecamatan Siak Kecil yakni sejak tahun 2008 sampai 2010, dan bidang usaha Gapoktan meliputi usaha pertanian dan peternakan.

Penelitian didesain sebagai metode survai deskriptif untuk melihat deskripsi peubah secara mendalam dengan unit analisisnya adalah Gapoktan, dan ditunjang dengan pendekatan kualitatif.

Populasi penelitian adalah Gapoktan penerima dana PUAP di Kecamatan Siak Kecil sejak tahun 2008 sampai tahun 2010 yang berjumlah sebanyak delapan Gapoktan yang terdiri dari 543 orang.

Metoda penarikan sampel menggunakan rumus Slovin sehingga diperoleh jumlah sampel sebanyak 121 orang responden. Kemudian dilakukan teknik penarikan sampel secara proportional stratified random sampling yakni proporsi jumlah sampel responden pada tiap Gapoktan, yang digolongan menurut tahun penerimaan.

Uji validitas menggunakan teknik product moment Pearson pada 13 orang responden diperoleh nilai kritis sebesar 0,553 artinya bulir pernyataan yang nilainya di bawah nilai kritis adalah tidak valid, kemudian dibuang dan nilai yang tidak terlalu jauh di bawah nilai kritis akan dimodifikasi kembali tata bahasanya agar lebih dipahami oleh responden.

Uji reliabilitas instrumen dalam penelitian ini menggunakan teknik belah dua memperoleh nilai koefisien sebesar 0,837 sehingga dapat dikatakan instrumen reliabel dan dapat digunakan.

Instrumen yang telah teruji validitas dan reliabilitasnya dijadikan pedoman untuk pengumpulan data dengan teknik wawancara dengan responden penelitian serta metode observasi lapangan. Disamping itu dilakukan teknik wawancara mendalam untuk menjembatani unit analisis tersebut sesuai dengan desain penelitian. Data yang terkumpul dianalisis secara statistik deskriptif.

\section{HASIL DAN PEMBAHASAN}

\section{Deskripsi Gapoktan Kecamatan Siak Kecil}

Gabungan kelompok tani (Gapoktan) adalah suatu organisasi petani yang merupakan gabungan dari beberapa kelompok tani yang berada di dalam satu wilayah (desa) yang dibentuk oleh para pengurus Poktan maupun KTNA dengan dukungan pemerintah seperti PPL dan aparat desa. Gapoktan sebagai pengelola dari program PUAP (Pengembangan 
Vol 6, No 2, Oktober 2011: $110-123$

Usaha Agribisnis Perdesaan) di Kabupaten Bengkalis telah dimulai sejak tahun 2008 sampai sekarang.

Gapoktan di Kecamatan Siak Kecil secara keseluruhan berjumlah 13 Gapoktan, jumlah Gapoktan penerima dana PUAP sejak tahun 2008 sampai dengan tahun 2010 berjumlah sebanyak delapan Gapoktan untuk delapan desa.

\section{Gapoktan Penerima Dana PUAP Tahun 2008}

Gapoktan Sumber Rezeki.-- adalah Gapoktan penerima dana PUAP untuk tahun 2008 yang berada di Desa Sei Siput. Gapoktan ini dibentuk berdasarkan berita acara pembentukan Gapoktan yang ditandatangani oleh kepala desa pada tanggal 11 April 2007. Kepengurusan Gapoktan terdiri atas: ketua, sekretaris, dan bendahara. Terdiri dari 10 kelompok, yang berawal dari sembilan Poktan dengan jumlah anggota sebanyak 250 orang.

Modal PUAP yang diperoleh dipergunakan di bidang peternakan yaitu budidaya kambing PE (peranakan etawa) sebanyak 100 ekor yang terdiri dari 91 ekor betina dan sembilan ekor jantan, tiap kelompok diberi 10 ekor kambing PE (sembilan ekor betina dan satu ekor jantan). Pada awalnya Gapoktan merencanakan modal tersebut dipergunakan untuk simpan pinjam dan saprodi tetapi rencana ini tidak terealisasi dikarenakan adanya perubahan kebijakan dari Ka. UPT Dinas Pertanian dan Peternakan (Distannak) Kecamatan Siak Kecil (ketika itu program PUAP masih dikelola oleh Distannak Kab. Bengkalis) dengan tujuan penyeragaman program untuk satu kecamatan. Dari modal dana PUAP 2008 tersebut UPT Distannak Kecamatan Siak Kecil membelikan kambing PE yang kemudian diserahkan ke Gapoktan, penyediaan kambing ini juga berlaku buat empat Gapoktan lainnya.

Kambing-kambing yang diberikan tidak dapat berumur panjang karena dengan masa yang sangat singkat hanya dalam waktu tiga bulan sejak didatangkan, kambing PE tersebut mati secara massal dan serentak. Hal ini diduga diakibatkan dari serangan penyakit atau virus dan diperparah lagi dengan pengetahuan petani akan pemeliharaan kambing PE masih sangat minim. Penyakit dari kambing PE ini ternyata menjangkiti kambing-kambing lokal sehingga banyak pula kambing lokal yang mati, hal ini menyebabkan kemarahan masyarakat kepada Gapoktan.

Jumlah kambing PE sekarang bersama anakannya lebih kurang tinggal 15 ekor, yang terbanyak ada di Kelompok tani Sido Makmur dan belum ada perguliran. Perjanjian pengembalian adalah pinjam satu kembali satu, yang dikembalikan bisa induk dan bisa anakan tergantung kesepakatan tiap kelompok tani. Bagi ternak yang mati (bukan karena kelalaian peternak) tidak dibebankan penggantian jika mati diakibatkan kelalaian seperti mati tergantung atau tidak dikasih makan maka akan diberikan sanksi yaitu disuruh membayar.

Pertemuan rutin Gapoktan dihadiri oleh pengurus-pengurus Poktan dan beberapa anggota Poktan lainnya sesuai kondisi, pertemuan dilakukan sesuai dengan kebutuhan Gapoktan. Pertemuan akan sering dilakukan ketika musim tanam datang terutama dalam 113 
Karakteristik Gabungan Kelompok Tani Penerima Program Pengembangan Usaha Agribisnis Pedesaan (Kasus Di Kecamatan Siak Kecil Kabupaten Bengkalis Riau) (Susy Hartati, Amiruddin Saleh dan Basita Ginting Sugihen)

menentukan jadwal tanam padi di lapangan dan juga membincangkan masalah-masalah yang ada di Gapoktan atau Poktan masing-masing, pertemuan sering juga dilakukan bersamaan dengan wirid yasin. Jika ada informasi mengenai suatu program akan disampaikan ke ketua Poktan dan kemudian akan disebar keseluruh anggota dengan cara lisan maupun menggunakan media handphone.

Gapoktan Usaha Maju.-- penerima dana PUAP untuk tahun 2008 yang berada di Desa Muara Dua. Gapoktan ini dibentuk berdasarkan berita acara pembentukan Gapoktan yang ditandatangani oleh kepala desa pada tanggal 17 Maret 2007. Kepengurusan Gapoktan terdiri atas: ketua, sekretaris, dan bendahara. Terdiri dari empat kelompok tani dengan jumlah anggota sebanyak 100 orang.

Bidang usaha yang direncanakan adalah peternakan. Kambing PE yang telah disediakan sebanyak 100 ekor (10 ekor jantan dan 90 ekor betina) kemudian disebar keempat kelompok. Namun dalam waktu yang singkat kambing PE tersebut banyak yang mati secara mendadak dan serentak sehingga jumlah kambing PE sekarang dengan anakannya lebih kurang 30 ekor dan telah dilakukan perguliran sebanyak tujuh ekor. Perjanjian pengembalian adalah satu kembali satu, bagi ternak yang mati (bukan karena kelalaian peternak) tidak dibebankan penggantian.

Pertemuan Gapoktan dilakukan menurut kebutuhan, namun dalam tiga bulan terakhir pertemuan Gapoktan jarang dilakukan. Jika ada informasi yang ingin disebarkan Gapoktan seperti informasi program pemerintah, akan dijelaskan di pertemuan malam wirid yasin mingguan.

Gapoktan Jaya Makmur.-- penerima dana PUAP untuk tahun 2008 yang berada di Desa Lubuk Gaung. Gapoktan ini dibentuk berdasarkan berita acara pembentukan Gapoktan yang ditandatangani oleh kepala desa pada tanggal 26 Februari 2007. Kepengurusan Gapoktan terdiri atas: ketua, sekretaris, dan bendahara. Terdiri dari 11 kelompok tani dengan jumlah anggota Gapoktan sebanyak 320 orang.

Perencanaan awal Gapoktan ini adalah simpan pinjam namun tidak sesuai dengan keinginan pihak UPT Distannak Kec. Siak Kecil karena RUB (rancangan usaha bersama) telah dahulu dibuat oleh UPT Distannak yaitu budidaya ternak kambing PE dan diseragamkan dengan Gapoktan lainnya. Kambing PE yang telah disediakan sebanyak 99 ekor untuk 11 kelompok tani, tiap kelompok diberi sembilan ekor kambing PE. Nasib Kambing-kambing tersebut sama dengan kambing di Gapoktan sebelumnya yaitu kambing PE tersebut mati secara massal dan serentak, dan pengetahuan petani akan pemeliharaan kambing PE juga masih sangat minim. Dari 99 ekor tersebut sekarang tersisa hanya tujuh ekor saja termasuk anakannya dan belum ada perguliran. Perjanjian pengembalian adalah 
Vol 6, No 2, Oktober 2011: $110-123$

satu kembali satu, bagi ternak yang mati (bukan karena kelalaian peternak) tidak dibebankan penggantian.

Pertemuan Gapoktan dilakukan menurut kebutuhan, informasi yang diterima Gapoktan akan diteruskan kepada ketua-ketua Poktan dan akan disosialisasikan ke anggota Poktan mereka masing-masing. Namun begitu, masih juga terdapat permasalahan komunikasi berupa tidak diteruskannya informasi tersebut dan anggota langsung mempertanyakan kembali ke pengurus Gapoktan. Dalam berkomunikasi antar sesama anggota terkadang timbul permasalahan seperti kecemburuan terhadap Poktan lain, namun hal ini dapat dijelaskan dan diselesaikan dengan baik.

Gapoktan Usaha Bersama II.-- penerima dana PUAP untuk tahun 2008 yang berada di Desa Sadar Jaya. Gapoktan ini dibentuk berdasarkan berita acara pembentukan Gapoktan yang ditandatangani oleh kepala desa pada tanggal 27 Maret 2007. Kepengurusan Gapoktan terdiri atas: ketua, sekretaris, dan bendahara. Terdiri dari 11 kelompok tani yang bergabung ke dalamnya dengan jumlah anggota sebanyak 275 orang.

Perencanaan usaha Gapoktan ini adalah ternak kambing. Kambing PE yang telah disediakan sebanyak 100 ekor untuk 11 kelompok tani, tiap kelompok diberi 9 sampai 10 ekor kambing PE. Kambing-kambing tersebut juga banyak yang mati akibat dari kurangnya adaptasi lingkungan atau stress yang dialami ternak namun masih dapat bertahan hidup sampai sekarang hingga 50 persen dan sudah ada perguliran. Perjanjian pengembalian adalah satu kembali satu yaitu anakan yang berumur 18 bulan, bagi ternak yang mati (bukan karena kelalaian peternak) tidak dibebankan penggantian.

Komunikasi Gapoktan lebih sering dilakukan secara informal karena pertemuan Gapoktan jarang dilakukan, pertemuan terakhir dilakukan pada tahun 2009. Jika ada informasi disebarkan dengan cara door to door bertemu di rumah atau dengan menggunakan media handphone.

Gapoktan Wana Jaya.-- penerima dana PUAP untuk tahun 2008 yang berada di Desa Bandar Jaya. Gapoktan ini dibentuk berdasarkan berita acara pembentukan Gapoktan yang ditandatangani oleh kepala desa pada tanggal 15 Maret 2007. Kepengurusan Gapoktan terdiri atas: ketua, wakil ketua, sekretaris, dan bendahara. Terdiri dari delapan kelompok tani dengan jumlah anggota sebanyak 200 orang.

Berdasarkan jumlah anggota tersebut, ternyata hanya pengurus-pengurus Poktan yang merupakan anggota langsung dari Gapoktan berjumlah 24 orang dan selebihnya hanya merupakan anggota tidak langsung. Informasi yang diterima oleh Gapoktan akan diteruskan kepada pengurus Poktan dan diharapkan informasi tersebut akan dikembangkan ke anggota Poktan lainnya. Namun, masih juga terdapat permasalahan komunikasi berupa tidak diteruskannya informasi tersebut ke anggota Poktan lainnya, selain itu juga terjadi kecemburuan sosial baik di bidang ekonomi maupun jabatan. 
Karakteristik Gabungan Kelompok Tani Penerima Program Pengembangan Usaha Agribisnis Pedesaan (Kasus Di Kecamatan Siak Kecil Kabupaten Bengkalis Riau) (Susy Hartati, Amiruddin Saleh dan Basita Ginting Sugihen)

Perencanaan usaha Gapoktan ini adalah ternak kambing. Kambing PE yang telah disediakan sebanyak 100 ekor untuk delapan kelompok tani, tiap kelompok diberi kambing antara 11 sampai 13 ekor kambing PE. Kambing-kambing tersebut juga banyak yang mati lebih dari 50 persen dalam setahun. Perjanjian pengembalian adalah satu kembali satu, bagi ternak yang mati (bukan karena kelalaian peternak) tidak dibebankan penggantian dan sudah terjadi perguliran sebanyak 10 ekor.

\section{Gapoktan Penerima Dana PUAP Tahun 2009}

Gapoktan Sri Tanjung.-- penerima dana PUAP untuk tahun 2009 yang berada di Desa Tanjung Damai. Gapoktan ini dibentuk berdasarkan berita acara pembentukan Gapoktan yang ditandatangani oleh kepala desa pada tanggal 3 Maret 2008. Kepengurusan Gapoktan terdiri atas: ketua, wakil ketua, sekretaris I, sekretaris II dan bendahara. Terdiri dari sembilan kelompok tani yang bergabung ke dalamnya, dengan jumlah anggota sebanyak 225 orang.

Perencanaan usaha bergerak di bidang peternakan yaitu ternak sapi. Dana PUAP dikelola oleh Gapoktan dalam bentuk penyediaan ternak sapi sebanyak 20 ekor dengan harga perekor sapinya sebesar lima juta rupiah. Pembayaran dilakukan dengan cara angsuran setiap bulan dengan membayar sebesar Rp. 150.000,- selama 40 bulan. Calon penerima atau orang yang akan menerima pinjaman disurvai oleh Gapoktan langsung ke masyarakat dan kelompok tani sampai berjumlah 20 orang, dengan kriteria adalah orangorang yang dapat bertanggung jawab dan atas dasar kepercayaan, karena tidak adanya jaminan atau agunan dalam peminjaman.

Modal diputar terus dan digulirkan pada tiap dua bulannya sehingga perguliran sudah terjadi sebanyak tujuh kali namun sistemnya tidak sama dengan sebelumnya yaitu anggota tidak disediakan sapi lagi tapi mereka diberikan uang tunai untuk membeli sapi sendiri sebesar lima juta rupiah. Sanksi akan diberikan jika ada anggota menunggak dalam pembayaran selama dua bulan berturut-turut dan diberikan kelonggaran sampai pada bulan ketiga, sapi akan ditarik dan dikelola oleh Gapoktan untuk sementara sampai yang bersangkutan menyelesaikan segala administrasi jika tidak maka angsuran sebelumnya akan hangus. Namun sanksi belum pernah dijatuhkan karena anggota selalu patuh dan taat atas segala aturan dan perjanjian yang telah disepakati.

Pertemuan rutin Gapoktan direncanakan tiga bulan sekali, namun jarang dilakukan karena kesibukan pada setiap anggota. Pertemuan akan dilakukan sesuai dengan kebutuhan (permasalahan) yang ada di Gapoktan, jika ada informasi mengenai PUAP atau program lainnya pengurus akan langsung mendatangi ketua-ketua Poktan dan informasi tersebut akan diteruskan ke anggota lainnya. 
Vol 6, No 2, Oktober 2011: $110-123$

Gapoktan Tanjung Permai.-- penerima dana PUAP untuk tahun 2009 yang berada di Desa Tanjung Belit. Gapoktan ini dibentuk berdasarkan berita acara pembentukan Gapoktan yang ditandatangani oleh kepala desa pada tanggal 15 Maret 2007. Kepengurusan Gapoktan terdiri atas: ketua, sekretaris, dan bendahara. Terdiri dari delapan kelompok tani yang bergabung ke dalamnya dengan jumlah anggota sebanyak 200 orang.

Dana PUAP dikelola oleh Gapoktan dalam bentuk pinjaman buat usaha tani anggotanya yang disalurkan ke kelompok tani dengan sistem pinjaman yang mereka sebut dengan tanggung renteng yaitu peminjaman dan pembayaran dilakukan secara berkelompok. Dana dikucurkan untuk empat kelompok sebesar 20 juta rupiah perkelompok dengan jumlah setiap kelompok sebanyak 10 orang sehingga setiap orang mendapat dua juta rupiah, jadi total keseluruhan penerima sebanyak 40 orang. Pembayaran ansuran sebesar Rp. 185.000,- perbulan selama satu tahun dengan bunga sembilan persen pertahun.

Kriteria calon penerima adalah orang-orang yang dapat dipercaya dan bertanggung jawab karena tidak diberlakukan adanya jaminan atau agunan dalam peminjaman. Sanksi akan diberikan kepada yang menunggak dengan denda seribu rupiah perhari namun sampai pada penelitian ini berlangsung sanksi tidak diberikan karena tidak ada anggota yang ingkar akan perjanjian.

Perguliran dana sudah terjadi, adanya penambahan sebanyak 45 orang peminjam yang bergerak di bidang usahatani pangan, kebun, ternak kambing, beli saprodi maupun kedai kecil-kecilan dan 40 orang penerima sebelumnya sudah melunasi pinjamannya.

Pertemuan Gapoktan direncanakan sebulan sekali, namun dalam prakteknya pertemuan Gapoktan dilakukan sesuai dengan kebutuhan di lapangan. Pertemuan akan lebih sering dilakukan ketika musim tanam datang yaitu menyeragamkan jadwal persemaian. Komunikasi dan interaksi pengurus Gapoktan lebih sering melalui ketua-ketua Poktan dalam hal penyebaran informasi dan dalam hal pembayaran anggota yang meminjam dana PUAP, karena sistem peminjaman dan pembayaran dilakukan secara berkelompok yang diketuai oleh ketua-ketua Poktan.

Memiliki usaha bersama di Gapoktan yaitu kebun sawit yang berasal dari tanah masyarakat, sedangkan bibitnya merupakan iuran anggota Gapoktan. Hasil kebun akan diperuntukkan untuk kegiatan sosial seperti pendidikan di desa tersebut.

\section{Gapoktan Penerima Dana PUAP Tahun 2010}

Gapoktan Maju Tani.-- penerima dana PUAP untuk tahun 2010 yang berada di Desa Lubuk Garam. Gapoktan ini dibentuk berdasarkan berita acara pembentukan Gapoktan yang ditandatangani oleh kepala desa pada tanggal 13 Juli 2007. Kepengurusan Gapoktan terdiri atas: ketua, wakil ketua, sekretaris, dan bendahara. Anggota sekarang berjumlah sebanyak 26 orang karena tidak semua anggota Poktan bisa secara langsung menjadi anggota 117 
Gapoktan, untuk menjadi anggota Gapoktan mereka harus mendaftar atau registrasi ulang. Ini bertujuan agar tertib administrasi dan identifikasi anggota sehingga jumlah anggota akan fleksibel karena terus berkembang. Terdiri dari 12 kelompok tani yang bergabung ke dalamnya.

Perencanaan usaha awalnya adalah di bidang penggemukan sapi, tapi kemudian diganti menjadi simpan pinjam dengan menyediakan sapi sebanyak 20 ekor untuk 20 orang calon penerima dengan harga perekor sebesar lima juta rupiah. Pembayaran dilakukan dengan cara angsuran setiap bulan dengan membayar sebesar Rp. 115.000,- selama empat tahun. Calon penerima adalah orang-orang yang dapat dipercaya dan memiliki agunan atau jaminan seperti surat tanah atau BPKB (Buku Pemilik Kendaraan Bermotor).

Sanksi akan diberikan kepada anggota yang tidak sesuai dengan kesepakatan atau perjanjian, barang (sapi) akan ditarik jika tiga bulan berturut-turut tidak membayar ansuran namun sampai penelitian ini berlangsung tidak ada anggota yang ingkar atau mangkir dari perjanjian. Bagi sapi yang mati karena bukan akibat dari kelalaian maka kesepakatannya akan hangus, tapi yang bersangkutan tidak akan mendapatkan pinjaman sampai empat tahun ke depan dan agunannya dikembalikan.

Sudah terjadi perguliran dana untuk enam orang yang membutuhkan penambahan modal di bidang usaha pertaniannya masing-masing dengan besaran pinjaman yang berbeda-beda tergantung proposal yang diajukan, maksimal lima juta rupiah perorang dengan bunga lima persen pertahun.

Informasi yang ada di Gapoktan akan diteruskan ke anggota dengan cara melakukan pertemuan atau menginformasikan dengan menggunakan media handphone.

\section{Karakteristik Gabungan Kelompok Tani Siak Kecil}

Karakteristik Gapoktan adalah ciri-ciri yang melekat pada suatu Gapoktan yang memungkinkan berlangsungnya suatu proses komunikasi antar sesamanya, kondisi karakteristik ini akan dapat membedakan suatu Gapoktan dengan Gapoktan lain. Karakteristik Gapoktan memiliki nilai skor rata-rata adalah 2,82 termasuk kategori baik, berarti keberadaan Gapoktan telah memberikan manfaat bagi anggotanya dan direspons dengan baik oleh para petani terutama anggota kelompok tani sebagai wadah pemersatu antar Poktan. Selanjutnya skor karakteristik Gapoktan Kecamatan Siak Kecil tersaji pada Tabel 1. 
Vol 6, No 2, Oktober 2011: $110-123$

Tabel 1. Rataan skor karakteristik Gapoktan Kecamatan Siak Kecil

\begin{tabular}{lc}
\hline \multicolumn{1}{c}{ Indikator Karakteritik Gapoktan } & Rataan Skor* $^{*}$ \\
\hline Norma & 2,89 \\
Tujuan & 2,77 \\
Keeratan & 2,80 \\
Kepemimpinan & 2,94 \\
Partisipasi anggota & 2,82 \\
Ukuran & 2,46 \\
\hline Rataan Skor Karakteristik Gapoktan & $\mathbf{2 , 8 2}$ \\
\hline Keterangan: *Internal skor 1,00-1,75 = Sangat Kurang; 1,76-2,51 = Kurang; 2,52-3,27 = Baik; & \\
3,28-4 = Sangat Baik &
\end{tabular}

Norma yaitu standar perilaku yang dapat diterima dan digunakan bersama oleh anggota Gapoktan dengan rataan skor sebesar 2,89 dengan kategori baik, berarti bahwa Gapoktan telah membuat dan menerapkan suatu norma bagi anggotanya dan dipatuhi oleh seluruh anggota berikut dengan sanksi yang diberikan. Terlihat dari adanya aturan yang berlaku untuk seluruh anggota memperoleh rataan skor sebesar 2,93. Aturan mudah dimengerti dan dilaksanakan sebesar 2,88. Kepatuhan dan ketaatan pada norma yang telah ditetapkan sebesar 2,90 dan diterapkan pula sanksi kepada anggota yang tidak mematuhi aturan tersebut sebesar 2,79 . Sanksi yang diberikan bisa berupa teguran, peringatan atau bahkan penarikan kembali modal atau pinjaman. Semua parameter indikator ini masuk pada kategori baik.

Norma adalah standar perilaku yang diterima di dalam suatu kelompok yang dirasakan bersama-sama oleh para anggota kelompok tersebut (Robbins 2002). Norma yang ada di Gapoktan Siak Kecil telah memberitahu para anggotanya apa yang seharusnya dan tidak seharusnya dilakukan pada situasi dan kondisi tertentu terutama dalam pengelolaan modal Gapoktan dan sanksi yang diberikan bisa berupa teguran, peringatan atau bahkan penarikan kembali modal atau pinjaman sehingga anggota taat kepada aturan yang berlaku di Gapoktan. Norma-norma tersebut telah menjadi sumber dasar hidup para anggota, ketaatan para anggota terhadap norma-norma itu menentukan ketaatan mereka terhadap kelompoknya. Menurut Soekanto (2007) bahwa suatu norma tertentu dikatakan melembaga (institutionalized), apabila norma tersebut: diketahui, dipahami atau dimengerti, ditaati dan dihargai.

Tujuan Gapoktan sudah jelas dan dipahami oleh anggota dengan nilai rataan skor sebesar 2,77 terkategori baik. Tujuan Gapoktan sudah diketahui dengan jelas memperoleh rataan skor sebesar 2,80 dan yang telah memahaminya sebesar 2,74 ke dua rataan skor ini termasuk kategori baik. Tujuan Gapoktan menurut responden adalah untuk 
Karakteristik Gabungan Kelompok Tani Penerima Program Pengembangan Usaha Agribisnis Pedesaan (Kasus Di Kecamatan Siak Kecil Kabupaten Bengkalis Riau) (Susy Hartati, Amiruddin Saleh dan Basita Ginting Sugihen)

mengembangkan usahatani anggota, meningkatkan ekonomi atau penghasilan petani, meningkatkan kesejahteraan anggota dan masyarakat serta sebagai pemersatu Poktan. Ini menunjukkan bahwa Gapoktan telah menjadi harapan dalam meningkatkan usahatani dan pendapatan mereka sesuai dengan kebutuhan dan keinginan anggota.

Suatu kelompok yang efektif mempunyai pengertian yang jelas tentang kegunaan dan tujuannya. Para anggota kelompok seringkali mempunyai interpretasi yang berbeda tentang kegunaan kelompok dan mempunyai tujuan-tujuan yang masing-masing sangat berbeda. Jika maksud serta tujuan kelompok cukup jelas dan para anggotanya merasa terikat olehnya, maka para anggota akan mampu untuk memusatkan tenaga pada tugastugasnya serta dapat mengukur kemajuan kelompok dengan patokan tujuan-tujuan yang telah ditetapkan itu (Sinaga 2002).

Keeratan terkategori baik memperoleh rataan skor 2,80 berarti anggota Gapoktan satu sama lain saling tertarik dan berkeinginan untuk tetap berada di dalam Gapoktan. Mereka merasa telah menjadi suatu bagian dari Gapoktan dan Gapoktan memiliki daya tarik. Terlihat dari ketertarikan terhadap Gapoktan dengan rataan skor sebesar 2,77 kesamaan kepentingan sebesar 2,74 dan perasaan memiliki terhadap Gapoktan sebesar 2,97. Semua parameter indikator ini masuk pada kategori baik.

Daya tarik untuk menjadi anggota Gapoktan membuat mereka tetap menyatu, Gapoktan telah memberikan kemudahan kepada mereka dalam berusahatani terutama dalam memperlancar pupuk bersubsidi, memperoleh bantuan dari pemerintah dan kebutuhan akan informasi sehingga usahatani diharapkan menjadi berkembang.

Sesama anggota dan Poktan memiliki kepentingan yang selaras dengan Gapoktan sehingga ikatan menjadi lebih kuat dan anggota merasa menjadi suatu bagian dari Gapoktan dan diperkuat oleh perasaan memiliki terhadap Gapoktan, akan menunjukkan keinginan untuk tetap bergabung karena telah dirasakan manfaatnya oleh anggota. West dan Turner (2009) menyebutkan bahwa kohesi merupakan lem yang menjaga agar kelompok tetap utuh. Sifat kohesif dapat mempengaruhi fungsi, efektif dan efisiennya suatu kelompok.

Kemampuan kepemimpinan yang dimiliki oleh ketua maupun pengurus Gapoktan dalam menjalankan tugas seperti kemampuan dalam mengambil keputusan, koordinatif dan komunikatif, kemampuan dalam bertindak dan mempengaruhi serta kemampuan dalam mengatasi konflik yang terjadi di dalam Gapoktan memiliki rataan skor sebesar 2,94 termasuk kategori baik. Berarti pemimpin atau pengurus Gapoktan Siak Kecil memiliki kemampuan yang baik dalam menjalankan tugasnya dan memiliki peranan yang sangat penting dalam mengatur roda kehidupan suatu Gapoktan. 
Vol 6, No 2, Oktober 2011: $110-123$

Hal ini terlihat dari kemampuan kepemimpinan ketua atau pengurus dalam pengambilan keputusan adalah baik, yang dilakukan dengan cara musyawarah dan hasil keputusan ini membuat anggota puas dengan diperoleh rataan skor sebesar 3,19. Lestari SB, Mindarti S, Ratnada M, Hadi J, Sidu D, Ramija K dan Gufroni LM (2001) berpendapat bahwa kelompok yang demokratis memiliki motivasi yang lebih besar terhadap pekerjaan, kepuasan anggota dan lebih tidak frustasi, keterlibatan banyak orang dalam diskusi dan tercapai kesepakatan pada atsmosfer yang demokratis menyebabkan sikapnya lebih positif terhadap keputusan tersebut.

Menurut pengamatan di lapangan, dalam pengambilan keputusan ada sebagian dari Gapoktan, tidak memberlakukan keputusan itu berlaku secara umum atau berlaku buat seluruh Poktan tetapi dilakukan secara khusus pada tiap Poktan. Artinya setiap Poktan bisa menghasilkan keputusan dan kesepakatan yang berbeda antar Poktan di dalam satu Gapoktan dan berlaku hanya buat Poktan tersebut, seperti keputusan dalam pengembalian ternak, ada yang mengembalikan induk dan ada pula yang mengembalikan anakan.

Kemampuan pemimpin dalam berkomunikasi dan mengkoordinir anggota adalah baik dengan rataan skor sebesar 2,91. Pengurus selalu mengkomunikasi informasi yang mereka terima dari petugas kepada anggota baik dalam bentuk door to door maupun dengan menggunakan media handphone. Kemampuan pengurus dalam bertindak sebesar 2,91 ini berarti ketua atau pengurus telah mampu menjalankan tugasnya dengan baik dan memiliki ketegasan dalam menjalankan kesepakatan yang telah ditetapkan.

Kemampuan pengurus dalam mempengaruhi anggota untuk berpartisipasi memiliki rataan skor sebesar 2,72 ini berarti ketua dan pengurus telah berperan penting dalam mengajak anggota untuk berpartisipasi dalam setiap kegiatan Gapoktan baik untuk pertemuan maupun menjalankan program pemerintah seperti ajakan untuk melaksanakan IP200 buat petani padi.

Kemampuan pengurus dalam mengatasi konflik juga baik, mendapat nilai rataan skor sebesar 2,96 dengan memberikan bantuan secara adil kepada anggota serta tanggap terhadap segala permasalahan yang ada sehingga setiap konflik dapat diselesaikan dengan baik.

Partisipasi anggota yaitu peran aktif anggota dalam setiap kegiatan yang dilakukan Gapoktan yang mendorongnya untuk memberikan sumbangan kepada Gapoktan baik dengan kehadiran, keaktifan maupun dalam menjalankan setiap kewajiban yang ditugaskan, memperoleh rataan skor sebesar 2,82 berkategori baik berarti anggota telah ikut berpartisipasi secara aktif.

Hal ini terlihat dengan kehadiran anggota Gapoktan pada setiap pertemuan atau kegiatan Gapoktan memperoleh skor rataan 2,83 dan keaktifan anggota sebesar 2,76 serta pelaksanaan kewajiban sebesar 2,86 . Semua parameter indikator ini masuk pada kategori 
Karakteristik Gabungan Kelompok Tani Penerima Program Pengembangan Usaha Agribisnis Pedesaan (Kasus Di Kecamatan Siak Kecil Kabupaten Bengkalis Riau) (Susy Hartati, Amiruddin Saleh dan Basita Ginting Sugihen)

baik. Anggota selalu berperan aktif dalam setiap pertemuan maupun kegiatan Gapoktan lainnya, dan melaksanakan setiap tugas dan kewajiban yang diemban dan diamanahkan kepada mereka. Anggota Gapoktan yang selalu menghadiri pada setiap pertemuan Gapoktan adalah para pengurus Poktan dan beberapa anggota Poktan yang diajak oleh pengurus Gapoktan sebagai perwakilan dari kelompoknya, tidak pernah sekalipun Gapoktan yang ada di Siak Kecil melakukan pertemuan akbar yang dihadiri oleh seluruh anggotanya dan mereka akan aktif berperanserta jika diminta oleh pengurus.

Ukuran adalah besaran atau jumlah anggota (orang) dalam Gapoktan, atau jumlah Poktan (buah) dalam Gapoktan, memiliki rataan skor sebesar 2,46 terkategorikan kurang, berarti ukuran atau besaran wadah Gapoktan belum ideal. Dilihat dari ukuran Poktan di Gapoktan dan jumlah anggota yang ada di dalam wadah Gapoktan masing-masing memiliki rataan skor sebesar 2,43 dan 2,48 kedua indikator terkategori kurang. Rakhmat (2005) mengutip pendapat McDavid dan Harari yang mengatakan apabila tugas memerlukan kegiatan yang konvergen (mencapai satu pemecahan yang benar), hanya diperlukan kelompok kecil supaya sangat produktif, terutama bila tugas yang dilakukan hanya membutuhkan sumber, keterampilan dan kemampuan yang terbatas dan apabila tugas memerlukan kegiatan yang divergen (seperti menghasilkan berbagai gagasan kreatif), maka diperlukan jumlah anggota kelompok yang lebih besar, lebih banyak kepala lebih baik.

Jumlah kelompok di Gapoktan berkisar 4 - 12 Poktan (rataan: 9 Poktan) dan jumlah anggota berkisar 24 - 320 orang (rataan: 178 orang), dalam hal ini yang menjadi anggota Gapoktan secara umum adalah anggota Poktan secara keseluruhan kecuali Gapoktan Wana Jaya dan Maju Tani yang memiliki persepsi yang berbeda. Anggota Gapoktan Wana Jaya adalah pengurus-pengurus Poktan yang berjumlah 24 orang merupakan anggota langsung dan anggota Poktan lainnya adalah anggota tidak langsung, sedangkan Gapoktan Maju Tani memberlakukan registrasi ulang kepada anggotanya.

Mengenai siapa yang menjadi anggota Gapoktan tidak begitu ditegaskan di dalam Peraturan Menteri Pertanian Nomor: 273/Kpts/OT.160/4/2007, namun tersirat dalam suatu pernyataan yang mengatakan bahwa pembentukan Gapoktan dilakukan dalam suatu musyawarah yang dihadiri minimal oleh para kontak tani atau ketua Poktan yang akan bergabung, setelah sebelumnya di masing-masing kelompok telah disepakati bersama para anggota kelompok untuk bergabung ke dalam Gapoktan (Deptan 2007). Hal ini berarti anggota Poktan juga adalah anggota Gapoktan. 
Vol 6, No 2, Oktober 2011: 110 - 123

\section{KESIMPULAN}

Karakteristik Gapoktan Kecamatan Siak Kecil berkategori baik di mana indikator norma, tujuan, keeratan, kepemimpinan dan partisipasi anggota tergolong baik, sedangkan indikator ukuran tergolong kurang, dan Gapoktan masih menjadi suatu harapan bagi petani dalam meningkatkan dan mengembangkan usahataninya.

\section{DAFTAR PUSTAKA}

[Deptan] Departemen Pertanian., 2007. Lampiran 1. Peraturan Menteri Pertanian Nomor 273/Kpts/OT.160/4/2007, tentang Pedoman Penumbuhan dan Pengembangan Kelompok tani dan Gabungan Kelompok Tani. Jakarta: Departemen Pertanian RI.

Lestari SB, Mindarti S, Ratnada M, Hardi J, Sidu D, Ramija K dan Gufroni LM., 2001. Manajemen dan komunikasi penyuluhan. Yogyakarta: Penyuluhan dan komunikasi pertanian UGM.

Sinaga N., 2002. Hubungan komunikasi interpersonal dalam kelompok tani dengan motivasi anggota (kasus pengembangan sentra agribisnis komoditas unggulan kambing peranakan etawa di kab. Kulonprogo). [tesis]. Bogor: Program Pascasarjana, Institut Pertanian Bogor.

Soekanto S,. 2007. Sosiologi: suatu pengantar. Jakarta: Rajawali Press.

Rakhmat J., 2005. Psikologi komunikasi. Bandung: Remaja Rosdakarya.

Robbins SP., 2002. Prinsip-prinsip perilaku organisasi. Alih bahasa Halida. Jakarta: Erlangga.

West R dan Turner LH., 2009. Pengantar teori komunikasi analisis dan aplikasi. Buku 1. Jakarta: Salemba Humanika. 